\title{
Notes of Honey Buzzard and Other Birds in Dumai and Rupat Island, Riau Province, Indonesia
}

\author{
Catatan Sikep Madu Asia dan Jenis - Jenis Burung Lainnya di Dumai dan Pulau \\ Rupat, Provinsi Riau, Indonesia.
}

\author{
Wishnu Sukmantoro ${ }^{1}$, Lim Kim $\mathrm{Cye}^{2}$, Lim Au Tiah ${ }^{2}$, Mohammad Iqbal ${ }^{3}$, Francis \\ $\mathrm{Ng}^{2}$ \\ ${ }^{1}$ Raptor Indonesia, Jl. Tumenggung Wiradiredja 216, Cimahpar Bogor 15116 \\ E-mail:wishnubio@yahoo.com * Penulis untuk korespondensi \\ ${ }^{2}$ Malaysian Nature Society, JKR 641 Jalan Kelantan, Bukit Persekutuan 50480 Kuala Lumpur, Malaysia \\ ${ }^{3}$ KPB Sos, Jl. Tanjung Api-Api km 3 Komplek P \& K Blok E1, Palembang 30152
}

Dumai are a town that located coastal area in the Nothern part of Pekan Baru, a capital city of Riau Province $\left(1^{\circ} 41^{\prime} 04.1^{\prime}\right.$ N, $101^{\circ} 26^{\prime} 14,1^{\prime \prime}$ E). Dumai is margined directly by Rupat Island and Bengkalis Island in the North and Duri District in the South and East. On February 17, survey is conducted in Dumai harbour which vegetation are dominated rural plant and small scale mangrove. Only few records of bird are reported on 1980 such as storm stork Ciconia stormi (Holmes 1980).

Rupat Island is one of islands in Riau Province in total some 70300 ha is located in Eastern plains of Sumatera $\left(1^{\circ} 70,2^{\prime}-2^{\circ} 5^{\prime} \mathrm{N}\right.$, $\left.101^{\circ} 30,5^{\prime}-101^{\circ} 72^{\prime} \mathrm{E}\right)$. Rupat Island is devide on big river in the nothern part from Titiakar until Pangkalan Buah, so that limitation rising is caused no bridge as an access from Northern part to the Southern or vice versa except boat or ships. Mangrove vegetation is dispersed in some sites such as Babi Island, Payung Island and Ketam island which all of them is located in surrounding Rupat. Mangrove vegetation in the boundary the beach are combined lowland forest types and swamp for small scale. Rupat is origined name from $\mathrm{Ru}(\mathrm{Ru}$ tree or Casuarina equisetifolia) that are estimated dominanly several years ago in Nothern part and 'Pat' from 'Perepat' or Bruguiera parvifolia that are dominantly in Southern part the island. Zalles \& Bildstein (2000) estimated migrants move across Rupat island from Bengkalis Island, $50 \mathrm{~km}$ to the NorthWest and directly across from Tanjung Tuan (Cape Rachado) in Malaysia, where migratings raptor are known to concentrate. Oriental honey buzzard Pernis ptilorhynchus and japanese sparrowhawk Accipiter gularis have been seen traveling in March at Bengkalis (Van Balen, 1994). The survey is held on February $18-19$ in Rupat Island which is concentrated in Tanjung Medang and Teluk Ru (Ru bay).

Data were collected in two sites; Dumai and Rupat Island. Honey buzzards were found in Tanjung Medang based on information from local people and estimated to fly across northern part of Rupat island from Malay Peninsula. The other birds were collected irregularly and concentrated in the rural habitat and mangrove includes bird records are along boat-track from DumaiTitiakar and Tanjung Medang.

In the survey, at least 39 species are found in Dumai and Rupat Island include honey buzzard. In Rupat Island which common myna Acridotheres tristis, yellow vented bulbul Pycnonotus goaivier and Lonchura malaccas are estimated to foremost as a terrestrial recident bird. Charadrius alexandrinus and Charadrius mongolus (include albino type*) also are recorded in migratory ahorebird groups.

At least 64 honey buzzard (Pernis ptilorhynchus) are recorded move in Rupat Island (Tanjung Medang) on February 18 at $1500 \mathrm{hrs}-1735 \mathrm{hrs}$. They moved into the island and estimated to the resting site. On February 19 at 0930 hrs -1300 hrs, 1081 honey buzzard are recorded to NorthEast passed across Malacca Strait to Malay Peninsula. They accrossed through several groups with flight variations (soaring and fledging). Wind direction are dominated from East to NorthWest and 20\% cloud coverages. Flight weight interval of raptors between 200 $\mathrm{m}-1 \mathrm{~km}$ from observer. 
Appendix 1. The list of birds in Dumai and Rupat Island is based on 2005 survey is exposed below; D: Dumai, R: Rupat Island, thr. Status: 2006 threatened status (red data book)

\begin{tabular}{|c|c|c|c|c|}
\hline No. & Name of Species & Date & Locations & Thr. status \\
\hline 1 & Common sandpiper Actitis hypoleucos & 17/2/2005 (1600 hrs) & $\mathrm{D}$ & \\
\hline 2 & Kentish Plover Charadrius alexandrinus & $18 / 2 / 2005$ & $\mathrm{R}$ & \\
\hline 3 & Lesser sand-plover Charadrius mongolus & $18 / 2 / 2005$ & $\mathrm{R}$ & \\
\hline 4 & White-bellied sea-eagle Haliaetus leucogaster & $17 / 2 / 2000$ & DR & \\
\hline 5 & Brahminy Kite Haliastur indus & $18 / 2 / 2005$ & DR & \\
\hline 6 & Honey buzzard Pernis ptilorhynchus & $18-19 / 2 / 2005$ & $\mathrm{R}$ & \\
\hline 7 & Black-winged Kite Elanus caeruleus & 19/2/2006 (0835 hrs) & $\mathrm{R}$ & \\
\hline 8 & Striated heron Butorides striatus & 17/2/2005 (1800 hrs) & $\mathrm{D}$ & \\
\hline 9 & Common Tern Sterna hirundo & $18 / 2 / 2005$ & $\mathrm{R}$ & \\
\hline 10 & Black-naped Tern Sterna sumatrana & $18 / 2 / 2005$ & $\mathrm{R}$ & \\
\hline 11 & Spotted dove Streptopelia chinensis & 18/2/2005 (1700 hrs) & $\mathrm{R}$ & \\
\hline 12 & Pink-necked pigeon Treron vernans & 19/2/2005 (0810 hrs) & $\mathrm{R}$ & \\
\hline 13 & Brown shrike Lanius cristatus & 19/2/2005 (0730 hrs) & $\mathrm{R}$ & \\
\hline 14 & Long-tailed shrike Lanius schach & 19/2/2005 (0750 hrs) & $\mathrm{R}$ & \\
\hline 15 & Large-billed crow Corvus macrorhynchus & 17/2/2005 (1750 hrs) & DR & \\
\hline 16 & Common Dollarfbird Eorystomus orientalis & $18-19 / 2 / 2005$ & $\mathrm{R}$ & \\
\hline 17 & Pied triller Lalage nigra & 18/2/2005 (0730 hrs) & $\mathrm{R}$ & \\
\hline 18 & Yellow-vented bulbul Pycnonotus goaivier & $17-19 / 2 / 2005$ & DR & \\
\hline 19 & Pied fantail Rhipidura javanica & 19/2/2005 (0740 hrs) & $\mathrm{R}$ & \\
\hline 20 & Pasific swallow Hirundo tahitica & $17-19 / 2 / 2005$ & DR & \\
\hline 21 & White-bellied swiftlet Collocalia linchii & $17-19 / 2 / 2005$ & DR & \\
\hline 22 & Edible-nest swiftlet Collocalia fucipaga & $17-19 / 2 / 2005$ & DR & \\
\hline 23 & Asian-palm swiftlet Cypsiurus balasiensis. & $18 / 2 / 2005$ & $\mathrm{R}$ & \\
\hline 24 & Waterfall swift Collocalia gigas & $17-19 / 2 / 2005$ & DR & NT \\
\hline 25 & White-throated kingfisher Halcyon smyrnensis & 19/2/2005 (0820 hrs) & $\mathrm{R}$ & \\
\hline 26 & Collared kingfisher Halcyon chloris & 17/2/2005 (1625 hrs) & $\mathrm{D}$ & \\
\hline 27 & Oriental dwarf kingfisher Ceyx erithacus & 19/2/2005 (0829 hrs) & $\mathrm{R}$ & \\
\hline 28 & Common myna Acridotheres tristis & $18-19 / 2 / 2005$ & $\mathrm{R}$ & \\
\hline 29 & Large-tailed nightjar Caprimulgus macrurus (?) & 18/2/2005 (1835 hrs) & $\mathrm{R}$ & \\
\hline 30 & Moustached babbler Malacopteron magnirostre & 19/2/2005 (0810 hrs) & $\mathrm{R}$ & \\
\hline 31 & Striped tit-Babbler Macronous gularis & 19/2/2005(0814 hrs) & $\mathrm{R}$ & \\
\hline 32 & Ashy tailorbird Orthotomus ruficeps & $17-19 / 2 / 2005$ & DR & \\
\hline 33 & Common tailorbird Orthotomus sutorius & $17-19 / 2 / 2005$ & DR & \\
\hline 34 & Dark-necked tailorbird Orthotomus atrogularis & 19/2/2005 (0901 hrs) & $\mathrm{R}$ & \\
\hline 35 & Yellow-bellied prinia Prinia flaviventris & 19/2/2005 (0841 hrs) & $\mathrm{R}$ & \\
\hline 36 & Bright-capped cisticola Cisticola exilis & 19/2/2005 (0740 hrs) & $\mathrm{R}$ & \\
\hline 37 & Black-headed munia Lonchura malacca & $18-19 / 2 / 2005$ & DR & \\
\hline 38 & White-headed munia Lonchura maja & 19/2/2005 (0910 hrs) & $\mathrm{R}$ & \\
\hline 39 & Eurasian Tree Sparrow Passer Montanus & $17-19 / 2005$ & DR & \\
\hline
\end{tabular}

\section{Aknowledgement}

We give apreciate to thank to Toru Yamazaki, President of Asian Raptor Research and Conservation Networking and Mike Chong, raptor migration project coordinator for ARRCN who supported the Rupat Island program with collaboration between Malaysia and Indonesia raptor watcher. We also give thank with Malaysia
Nature Society, Raptor Indonesia (Bird of Migration Watch program), PILI-NGO Movement especially Iwan Setiawan, Adam Supriatna and Dr. M. Indrawan (Indonesia Ornithologists' Union/IdOU). We also thank you so much for Hamzir Mahad as a head of Teluk Ru and some people who helped this program. 


\section{References}

Holmes, D. A. 1996. Sumatra Bird Report. Kukila 8:956.

Lim Kim Seng. 1997. Notes of Booted Eagle Sighting on Bintan Island, Riau Archipelago. Kukila 9:74-77

MacKinnon, J., Karen Phillipps \& Bas Van Balen. 1992. Burung-Burung di Sumatera,Jawa, Bali dan Kalimantan (Termasuk Sabah, Serawak dan Brunei Darussalam). Jakarta: Puslitbang Biologi LIPI.

Rajathurai, S. 1996. The Birds of Batam and Bintan Islands, Riau Archipelago. Kukila 8:86113.
Sukmantoro, W. 2001. Panduan Burung Pemangsa Asia di Indonesia. Bogor: Asian Raptor Migrant Indonesia Information Centre.

Sukmantoro, W. 2002. 2001 Report and Analysis on Asian Raptor Migration in Sumatra, Java and Bali. ARRCN Report. Indonesia

Tilford, T. 2000. Birds of Java, Sumatera and Bali. UK: New Holland Publisher.

Zalles I. J. and K. L. Bildstein. 2000. Raptor Watch. A Global Directory of Raptor Migration Sites. Birdlife Conservation Series No. 9. USA: Hawk Mountain Sanctuary. 